\title{
The State of Labour and Working-Class History in Europe
}

\author{
Talja Blokland \\ Amsterdam School for Social Research
}

Europe's scholars of labor history gathered in The Netherlands in February 1997 to discuss nothing less than the state of their profession. The meeting opened at the Rotterdam Maritime Museum, a location that offered a fine historical exposition on Rotterdam dockworkers during the first day's lunch break. The second day of the conference was hosted by the organizers of the conference at the International Institute of Social History (IISH) in Amsterdam. The Institute's director, Marcel van der Linden, opened the conference with remarks about its goals and themes. Since national histories are doomed to become marginal as capital and labor become global, contrasting and comparing become all the more crucial, he proclaimed. The conference would feature such work, and take the inaugural steps to found a network of labor historians in Europe-Labnetwhich, besides encouraging transnational historical work, would respond to shifts in research funding from the national to the united European level.

The additional theme of papers presented during the conference was the strengths and weaknesses of present writing in European labor history. What has been successful? What substantial issues are most fruitful for future collaborative work? These questions were introduced in general terms by Jürgen Kocka (Free University, Berlin), who investigated trends in labor history's programmatic statements as well as its research results. Programmatic articles published over the last few years evoke a sense of crisis and a highly fragmented search for solutions, he noted, all of them discrediting traditional class formation analyses. An inventory of articles published in International Labor and Working-Class History and The International Review of Social History in the last decade did not indicate much evidence of a paradigm shift, however. The turbulent situation diagnosed at the theoretical level, Kocka asserted, is becalmed when one looks at the actual output of labor history.

Kocka called for the discipline to take on the new challenges posed by changes in the political and intellectual background against which labor history has been written in the last fifteen years or so. Referring to a wide range of work, from the history of civil society to gender history, Kocka's conclusions were, roughly summarized, threefold: Get politics back in; give the history of work new prominence; and make comparisons outside the western world. This last point provoked discussant Simonetti Soldani (Passato e Presente) to express the hopes that comparisons would eventually go beyond the same old English, French, German, and US cases and that Labnet would contribute to greater awareness of the variety of European 
history. Last but not least, "Read Marx," concluded Kocka: The new and imminent forms of capitalist crisis will make anticapitalist visions of the past interesting again.

Gender history was one of the substantial issues for debate, as Eileen Yeo (University of Sussex, Brighton) made clear in her vivid presentation of the importance of sex and gender to men, women, and history. Yeo brought up the issue of identity for the first time-an issue that would become the jack-in-the-box of the conference, popping up at moments both expected and surprising. Labor historians are catching up with the social scientists in the fashion of identity-talk, it seems; the term sounds good and fits everything. Unfortunately, clarity about what is meant precisely by "identity" did not receive the attention necessary to avoid suspicions that conferees were using a fashionable term without much analytical gain.

For Yeo, no matter what collective identities we prioritize at different moments, gender is always there. When our social identities are primarily seen in terms of class, race, ethnicity, or nationality, we nonetheless experience ourselves as men and women. No history can do without a gender dimension, she argued. Although discussant Birgitte Studer (Universität de Lausanne) concurred on the importance of gender, she considered identities less fixed and homogeneous facts than Yeo seemed to have suggested, and argued for "deconstruction" of the term.

Including gender in working-class histories was a matter that Yeo discussed in a more down-to-earth manner by assessing the state of the art in horizontal studies (gender issues within the working class), diagonal studies (men from one class and women from another), and the relatively unexplored territory of vertical power relations between women of different classes, where Yeo's own research concentrates. It led her to the conclusion that "the whole area of presumed unity between women and workers, on closer inspection, is riddled with the tensions that bedevil (or bewitch!) the relationship between the professional/managerial class and the lowerpaid working class that have complicated relations among women as well as relations among men."

Class, presented as a commonly understood concept up to this point, was complicated by Mike Savage (Manchester University), who took up the issue in a substantial theoretical paper. Deftly combining historical and sociological literatures, Savage posed an alternative to the growing doubts and uncertainties about the relevance of class. He avoided the endless debate of cultural versus economic class theories and made his way through the Marxian/Weberian controversy by arguing for a focus on working-class life as a project with insecurity at its core. Savage posed questions about strategies workers used, how these were related to labor movements, and how these findings can be generalized-which beg, Savage asserted, further questions about the contexts of workers' lives, both in time and, especially, in space. Citing work by American historical sociologists, Savage proposed to widen the scope of labor history by paying more attention to 
the spatial distribution of class networks. Spatial sensitivity would make it possible to explore the complex linkages between class structure, demographic change, and forms of political mobilization. One of the discussants, Klaus Tenfelde (Institut zur Erforschung der Europaeischen Arbeiterbewegung, Bochum), was not convinced, however. While praising Savage's interest in network analysis, he thought his redefinition of the concept of class would not really change research strategies. "Insecurity," he thought, was too amorphous to be useful.

Patrick Pasture (Katholieke Universiteit, Leuven) opened the second day of the conference with yet another substantive category for labor history: religion. The view that religion's role in the history of European labor is described by the word "secularization" was clearly and concretely challenged by this presentation. The identity jack-in-the-box reappeared in the less successful parts of Pasture's story, however, where he professed that the working class is not homogeneous and has multiple identities, of which religion is one-and one that, of course, deserves more attention. The reiteration of this formula was less informative than Pasture's extensive accounts of the development of Christian labor movements in Belgium.

A final paper was presented by John Belchem (University of Liverpool), who also brought up the issue of identity - this time focusing on ethnicity and its relevance in working-class life. Presenting the experiences of Irish migrants to the United States, Belchem told stories that revealed some of the structural strengths and weakness of ethnic mobilization. He showed how Irish stereotypes were imposed on migrants and how these provoked the development of ethnic pride and helped build ethnic networks that shaped their contribution to the "American house of labor." Belchem argued for studying ethnicity as a relational category and against regarding ethnicity as divisive to working-class collectivism-the latter a view that the most interesting labor history is now abandoning, Belchem suggested, in favor of perspectives suggesting a symbiotic relationship between ethnicity and class.

Only a few of the fertile discussions that took place at the conference are presented here. Fortunately, the discussions continue via Labnet, an e-mail discussion list launched at the conference that gives all those interested in these issues an opportunity to pursue them (to take part, send an e-mail message containing only the words SUBSCRIBE LABNET to LISTSERV@iisg.nl). Discussions are already fulfilling that promise, and it will surely serve as a venue where the issues that define future face-to-face conferences on the future of labor and working-class history will be discussed in advance. 